\title{
Rasional Instrumental dan Komersial Petani
}

\author{
Latang \\ Dosen Jurusan Pendidikan Luar Sekolah FIP UNM \\ Jl. Tamalate 1 Tidung Makassar \\ Corespondensi: latang1962@gmail.com
}

\begin{abstract}
Abstrak: Tujuan penelitian ini adalah meningkatkan kompetensi berinovasi petani dan berusahatani secara komersial. Target khusus yang ingin dicapai adalah menganalisis proses berusahatani untuk meningkatkan kesejahteraan masyarakat. Metode pencapaian tujuan adalah mengimplementasikan strategi intensifikasi, ekstensifikasi, diversifikasi, rehabilitasi pertanian dan bekerjasama dengan penyuluh pertanian serta untuk menganalisis hasil tindakan rasional intstrumental dan tindakan komersial. Hasil penelitian ini mendeskripsikan inovasi yang dikembangkan oleh petani dan inovasi yang diperoleh daripenyuluhpertanian. Penelitian inidilaksanakan di PallimeKabupatenBone. Temuan penelitian ini dapat menggambarkan teknik berinovasi, berintensifikasi dan diversifikasi agar dapat menproduksi hasil pertanian yang berkualitas ekspor. Sedangkan temuan lain, petani dapat meningkatkan kompetensi berusahatani yang secara komersial. Lagipula, hasil penelitian dapat dijadikan referensi pengembangan ilmu pengetahuan dan teknologi dibidang pertanian. Penelitian ini dapat berimplikasi terhadap peningkatan kesejahteraan masyarakat yangberada di Pallime Kabupaten Bone. Kesimpulan penelitian ini adalah petani berusaha tani yang sesuai dianjurkan penyuluh pertanian dan pengalamannya berusahatani. Petani memilih kegiatan usahatani yang dapat menguntungkan secara komersial dari tindakan rasionalnya.
\end{abstract}

Kata kunci: rasional instrumental, komersial, inovasi, intensifikasi

Abstract: The objective of this research is to improve the competence of farmers innovation and to commercially work. Specific targets to be achieved are analyzing the process of trying to improve people's welfare. The goal achievement method is to implement intensification, extensification, diversification, agricultural rehabilitation and cooperation with agricultural extension and to analyze the result of intstrumental rational action and commercial action. The results of this study describe the innovations developed by farmers and the innovations gained from agriculture. This research is conducted in Pallime Kabupaten Bone. The findings of this research can illustrate the techniques of innovating, intensifying and diversifying in order to produce export quality agricultural products. While other findings, farmers can increase the commercial competence of farming. Moreover, the results of research can be used as reference for the development of science and technology in the field of agriculture. This research can have implication to the improvement of people's prosperity which is in Pallime of Bone Regency. The conclusion of this research is farmer try farmer which suitable agriculture extension advocate and experience of farming. Farmers choose farming activities that can be commercially profitable from their rational actions. Farmers prioritize commercial benefits and optimal added value.

Keywords: instrumental rational, commercial, innovation, intensification 


\section{PENDAHULUAN}

Masyarakat mengimplementasikan ilmu pengetahuan dan pengalaman berusahatani untuk meningkatkan kesejahteraan. Masyarakat menyadari pentingnya berusahatani untuk memenuhi kebutuhan pokok dan kebutuhan untuk meningkatkan pendapatan agar kehidupan lebih sejahtera. Kegiatan yang dilakukan berkaitan erat dengan pengalaman dan pengetahuan yang diperoleh dari pembelajaran sosial dan pemerintah atas program-program yang dilaksanakan pemerintah terhadap peningkatkan kesejahteraan

Konsep ini memberikan wawasan kepada pihak petani bahwa upaya-upaya yang dilakukan pemerintah berdampak positif terhadap kesejahteraan. Khusus pelaksana penyuluhan pertanian memberikan kontribusi positif sehingga masyarakat turut merasakan hasil yang diperoleh dari usahatani yang bersifat modern. Rasional instrumental dan komersial ini dipahami masyarakat untuk mengoptimalkan usahatani yang dilakukan di lapangan. Mereka tentunya berpikir positif untuk mencari kebutuhan dasar dan kebutuhan terhadap keuntungan dalam berusahatani.

Urgensi dalam kajian ini adalah kompetensi praksis petani dalam mengelola usahatani terwujud secara signifikan dengan tingkat kesejahteraan dalam pemenuhan kebutuhan hidup. Tujuan ini mendorong petani mencari teknik berinovasi agar hasil usahatani dapat berkualitas ekspor. Petani berupaya untuk belajar tentang diversifikasi produk agar produksi dapat ditingkatkan baik secara kuantitas maupun kualitas.

Ditinjau dari dampak positif dalam rasional instrumental dan komersial ini memungkinkan petani melaksanakan dengan serius usaha intensifikasi dan diversifikasi untuk meningkatkan kuantitas dan kualitas produksi agar dapat dijadikan produksi yang berkualitas ekspor. Petani mengoptimalkan produksi kepiting, dan rumput laut untuk ekspor. Lagi pula, diharapkan petani dapat berupaya secara diversifikasi hasil usahatani untuk meningkatkan nilai jual sehingga kehidupan petani di desa Pallime Kabupaten Bone dapat menjadi lebih sejahtera.

Masyarakat yang berada di desa Pallime Kabupaten Bone melaksanakan kegiatan berusahatani dan mereka mengharapkan bantuan yang serius dari pihak pemerintah mengenai produk yang telah dihasilkan dapat disalurkan dan dipasarkan dengan harga yang sesuai dengan harga pasar internasional. Tentunya petani membutuhkan informasi proses perdagangan internasional, oleh karena itu maka pemerintah diharapkan dapat menginformasikan dan melindungi petani dari pihak tengkulak agar petani termotivasi untuk berusahatani untuk meningkatkan produksi pertanian.

Di lapangan telah terlihat kenyataan bahwa hasil produksi petani terjadi penurunan harga sehingga petani kurang termotivasi untuk melaksanakan usahatani yang optimal. Berdasarkan pengalaman petani jika produksi semakin meningkat maka pihak pedagang berupaya membeli hasil produksi sangat murah. Kendala inilah membuat petani semakin terpuruk. Keterlibatan pemerintah untuk menangani masalah ini yang merupakan solusi terbaik untuk meningkatkan kesejahteraan petani.

Berdasarkan solusi-solusi yang diharapkan petani adalah pihak pengambil kebijakan me ne ntukan langkah-langkah yang tepat untuk menyalurkan produksi petanian yang bernilai ekspor dan diberikan harga yang disesuaikan dengan perdagangan internasional, seperti ketentuan dengan nilai harga internasional pada produk yang dihasilkan petani sehingga mereka dapat menjadi sejahtera.

Pelaksanaan yang secara intensif mengenai intensifikasi dan diversifikasi dapat berkontribusi terhadap kesejahteraan petani. Di samping itu, kegiatan ini dapat berkontribusi terhadap pengembangan ilmu pengetahuan dan teknologi khusus di bidang pertanian. Permasalahan adalah menganalisis proses pengembangan IPTEK dan peningkatan kesejahteraan masyarakat khusus di desa Pallime Kabupaten Bone dan pelaksaanaan intensifikasi pertanian, menganalisis proses pengolahan produk atau diversifikasi usahatani dan menganalisis proses perdagangan hasil produksi serta menganalisis tindakan rasional instrumental dan komersial petani terhadap kesejahteraan.

Perkembangan pertanian dapat dipantau melalui pelaksanaan intensifikasi pertanian, diversifikasi produk pertanian dan perkembangan perdagangan nasional dan internasional. Kontribusi pemerintah terhadap pelaksanaan program pertanian untuk kesejahteraan dan menciptakan teknologi diversifikasi produk yang berkualitas. Melalui proses teknologi pada produksi akan memberikan jaminan kualitas 
menuju pasar internasional. Pelaksanaan program pertanian dapat berkontribusi terhadap kesejahteraan petani dan memberikan kesempatan untuk peningkatan kompetensi petani. Disamping itu, proses praksis dari pengetahuan dan pengalaman berimplikasi pada peningkatan kesejahteraan.

Memantau kegiatan berusahatani dan aktivitas pelaksanaan intensifikasi dan diversifikasi produk. teknik-teknik pengelolaan tambak dan mendesiminasikan informasiinformasi yang relevan dengan pengembangan usahatani tambak kepiting, rumput laut, udang, ikan. Mediseminasikan inovasi yang dikembangkan dalam rangka peningkatan produksi dan pengolahan produksi yang berkualitas ekspor. Mendiseminisikan pengembangan IPTEK di bidang pertanian.

\subsection{Rasional instrumental dan komersial}

Menurut Narwoko (2006) menjelaskan bahwa tindakan sosial adalah kemampuan untuk berempati atau kemampuan untuk menempatkan diri dalam kerangka berfikir dan tindakan sosial yang dilakukan seseorang didasarkan atas pertimbangan dan pilihan sadar yang berhubungan dengan tujuan tindakan itu dan ketersedian alat yang dipergunakan untuk mencapainya.

Dihubungkan dengan tindakan sosial yang tercakup dalam rasional instrumental petani dapat diartikan bahwa petani berupaya untuk berfikir kritis untuk memilih suatu tindakan yang mengubah hidupnya yang lebih baik. Upaya- upaya yang dilakukan berkaitan erat pengalaman mereka dan pengetahuan yang diperoleh melalui pembelajaran sosial dan pemerolehan pengetahuan yang disampaikan oleh ahli-ahli di bidang pertanian.

Lagi pula, tindakan sosial dalam kaitan tindakan rasional komersial petani adalah upaya petani berusahatani untuk mencari keuntungan. Hal ini dapat diartikan bahwa petani mencoba berbagai teknik-teknik untuk meningkatkan produksi sehingga dapat mereka memperoleh keuntungan ganda. Kemampuan rasional instrumental dan komersial petani dapat mengakibatkan terjadi perubahan atau perkembangan dalam berusahatani yang berdampak peningkatan kesejahteraan.

Salman (2006) menjelaskan penyadaran merupakan proses di mana petani difasilitasi untuk mencapai kesadaran kritis tentang substansi masalah yang dihadapi, dalam hal ini rendahnya kualitas pasca panen.

Menganalisis masalah rendahnya kualitas pasca panen yang dijelaskan di atas maka petani diberikan bantuan untuk dapat mengolah produksi secara diversifikasi untuk meningkatkan kualitas produksi agar keuntungan petani dapat lebih meningkat. Kesadaran kritis inilah petani dapat mengambil tindakan rasional instrumental.

Menurut Habermas (dalam Hardiman, 1993) bahwa rasionalisasi instrumental mendominasi rasional nilai. Pada sisi lain, tindakan tradisional juga masih terjadi, dalam bentuk masih berpengaruhnya magik dan mistik. Sedangkan menurut Weber (1978) rasionalitas nilai bukanlah tipe ideal masyarakat industri adalah rasional instrumental. Germani (1981) menjelaskan bahwa semakin bergeser ruang normatif dari ciri preskriptif ke ciri elektif maka semakin memungkinkan terjadinya rasionalisasi tindakan.

Sesuai dengan uraian ini diinterpretasikan bahwa seorang individu atau petani semakin hari terjadi pergeseran damatif ke elektif atau rasional instrumental untuk lebih meningkatkan produksi dengan tujuan komersial. Secara rasionalisasi tindakan menuju perkembangan pemikiran bagi petani lebih mencari keuntungan dalam usaha taninya.

\subsection{Petani}

Petani dalam konsep itu terdapat tiga konsep yakni cultivator (pencocok tanam), peasant (petani pedesaan) dan farmer (pengusaha tani). Menurut Wolf (1983) ketiga konsep ini, maka peasant dapat dipahami bahwa peasant itu merupakan petani yang cenderung bercocok tanam dan beternak. Peasant (petani pedesaan) tidak melakukan usaha dalam arti ekonomi, ia mengelola sebuah rumah tangga, bukan sebuah perusahaan bisnis. Cultivator adalah petani yang bersifat primitif, sedangkan farmer adalah petani pengusaha yang merupakan sebuah perusahaan, yang mengkombinasikan faktor-faktor produksi, yang dibeli di pasar untuk memperoleh laba dengan jalan menjual hasil produksinya secara menguntungkan di pasar hasil bumi.

Wolf (1983) menambahkan tentang bentuk-bentuk ekotipe paleoteknik yang utama adalah: 1) sistem di mana tanah yang tandus dibiarkan menganggur untuk jangka waktu lama, yang dikaitkan dengan pembakaran hutan untuk membuka tanah dan bercocok tanam dengan 
menggunakan tajak, 2) sistem tanam sebagian, dimana tanah yang dapat ditanami dibagi menjadi dua sektor atau lebih, yang ditanami selama dua sampai tiga tahun, lalu dibiarkan kosong selama tiga atau empat tahun, 3) sistem tanam bergilir dengan siklus singkat, 4) sistem tanam permanen yang berkaitan dengan teknik untuk menjamin adanya persedian air permanen bagi tanaman yang sedang tumbuh, 5) penanaman permanen lahan pilihan yang dikombinasikan dengan satu jalur tanah di daerah belakang yang dimanfaatkan secara sporadis

Dipertegas Wolf (1983) bahwa ekotipe neoteknik yang sejalan perkembangan revolusi industri adalah: 1) pengolahan tanah pertanian sepanjang tahun, dibantu oleh pengembangan rotasi jenis tanaman dan penggunaan pupuk, 2) perbaikan mutu tanaman dan ternak, 3) didatangkannya tanaman-tanaman yang sama sekali baru dari daerah lain, 4) digunakannya mesin-mesin baru. Kemajuan- kemajuan itu direvoluionerkan lebih lanjut dengan digunakan mesin uap dalam pertanian.

Dari dua jenis sistem tersebut di atas maka dapat dihubungkan keadaan petani di desa untuk mengikuti dimana yang dianggap paling cocok dengan rasional instrumental dan tindakan komersial. Tentu hal ini, dapat dianalisis bahwa menuntut petani lebih berpikir kritis yang berkaitan upaya peningkatan produksi dan keuntungan untuk kesejahteraan semakin meningkat.

\subsection{Inovasi Petani}

Petani mencari inovasi untuk memudahkan usahatani dan meningkatkan produksi. Petani giat dalam kelompok untuk bertukar pengalaman yang berhubungan dengan usahataninya. Dijelaskan Yulianti (2003) penerimaan sebuah inovasi bukan merupakan sesuatu yang mutlak. Penerimaan inovasi merupakan suatu proses yang dinamis dimana sebuah inovasi bisa jadi diterima pada suatu waktu dan pada waktu lain akan ditolak. Inovasi akan diterima apabila sebuah inovasi tidak memberikan sesuatu yang lebih bagi sebuah masyarakat bisa saja suatu waktu inovasi itu akan ditolak oleh masyarakat begitulah proses penerimaan inovasi merupakan proses dinamis dari masyarakat terkait dengan berbagai penilaian masyarakat.

Menurut Rodger dan Shoemaker (1987) menjelaskan tentang tahapan proses pengambilan keputusan dalam suatu inovasi. Proses pertama adalah pengenalan, dimana seseorang mulai untuk memahami dan mengerti tentang apa itu inovasi yang akan ditawarkan. Proses selanjutnya adalah persuasi dimana seseorang sudah memasuki tahap pembentukan sikap mengenai inovasi tersebut. Yang ketiga adalah keputusan dimana seseorang terlibat dalam berbagai kegiatan yang akan mengarah pada menerima atau menolok inovasi. Pada saat inilah keadaan kritis dimana seseorang akan memutuskan apakah menerima atau menolak inovasi. Tahap selanjutnya adalah komfirmasi atau tahapan untuk menambah penguatan apakah inovasi itu diterima atau tidak. Hal itu tentu terkait dengan hasil dari pada inovasi itu sendiri apabila sesuai dengan keinginan akan diterima apabila tidak tentu akan ditolak.

Sehubungan dengan uraian di atas dapat dipahami bahwa petani tentu akan menerima inovasi yang dianggap dapat menambah dan meningkatkan hasil dari usahatani. Jika keadaan usahatani dianggap dapat merugikan maka mereka akan menolak inovasi. Daya kritis petani tentu telah dipertimbangkan tentang keuntungan atau kerugian apabila mereka memutuskan inovasi baru tersebut.

Disamping itu, petani dapat berupaya untuk menciptakan inovasi baru yang disesuaikan dengan pengalaman belajar mereka. Kecenderungan berinovasi bagi petani dilandasi dengan pemerolehan dan pembelajaran masyarakat tentang teknik peningkatan produksi dari usahataninya. Mereka belajar terus dan berusaha mengembangkan usaha-usaha yang dilakukan di lapangan dan dihubungan dengan keadaan alam digeluti dan bercengkrama bertahun-tahun dengan alam sehingga inovasi yang diciptakan dapat membantu dalam peningkatan usahatani.

Ditambahkan Yulianti (2003) dalam masyarakat sendiri penyebaran terjadi .penemuan baru berupa gagasan, alat dan berbagai teknologi baru sementara invention adalah kemauan masyarakat menerima gagasan dan teknologi baru tersebut. Inovasi pada dasarnya adalah proses pembaharuan yang terus menerus dalam masyarakat yang menuju pada kesempurnaan. Keterkaitan dua hal tersebut dalam pelapisan sosial dan proses penyebaran inovasi tentu akan berpengaruh pada cepat tidaknya proses penyebaran inovasi terjadi.

Diseminasi informasi tentang masalah pertanian maka petani secara sadar akan mempertimbangkan secara kritis untuk menerima 
atau menolak inovasi. Petani tentu memperlajari masalah tersebut yang diduga dapat memberikan keuntungan dalam berusahatani. Jika inovasi telah diterima secara sempurna dan diaplikasikan dalam usahataninya, maka petani dapat memperoleh keuntungan berupa produksi dan kesejahteraan dapat lebih meningkat.

Ditegaskan Rodgers (1962) dan Summer (1983) tentang peranan individu inovatif dalam adopsi teknologi. Teknologi tersebut diadopsi individu inovatif dalam komunitas yang selanjutnya menyebar. Adopsi oleh individu inovatif merupakan pola perkembangan teknologi dalam komunitas industri.

Berkaitan dengan uraian ini dipersepsi bahwa adopsi teknologi sasaran utamanya adalah komunitas industri. Namun hal ini, inovasi seharuskan diterapkan pada bidang pertanian. Komunitas petani juga diharapkan dapat mengaplikasikan inovasi-inovasi agar produksi pertanian lebih meningkat.

\subsection{Petani Komersial}

Di era ini, petani cenderung berupaya untuk bertani komersial. Mereka mempertimbangkan tentang pembiayaan dalam berusahatani dan hasil yang diperoleh dapat lebih meningkatkan keuntungan. Jika seorang petani tidak melaksanakan usahatani yang secara modern, maka mereka dapat tertinggal dan sangat dituntut untuk pemenuhan kebutuhan yang serba kompleks. Petani modern berinovasi secara optimal. Mereka menggunakan alat yang modern untuk mengolah intensifikasi dan diversifkasi produk.

Menurut Sanderson (1995) setiap masyarakat mempunyai sistem ekonomi yang terjalin sangat dekat dengan pola teknologi subsistensinya. Namun, ada perbedaan krusial antara ekonomi dan teknologi. Teknologi meliputi alat, teknik dan pengetahuan yang dimiliki para anggota masyarakat dan digunakan dalam proses pemenuhan kebutuhan hidup. Aktivitas ekonomi tidak mungkin ada tanpa teknologi, tetapi ekonomi adalah sesuatu yang lebih dari sekedar teknologi. Ekonomi berisi hubungan-hubungan sosial yang mengorganisasikan produksi, distribusi dan pertukaran barang dan jasa dalam suatu masyarakat.

Mencermati uraian di atas menunjukkan bahwa petani sangat dekat dalam penggunaan teknologi, alat, dan pengetahuan yang dimiliki untuk diterapkan agar produksi lebih banyak dan berkualitas sehingga dapat mempengaruhi pendapatan dan kesejahteraannya. Setiap petani diharapkan dapat bertani secara komersial.

Menurut Raharjo (2004) bahwa proses komersialisasi khususnya dalam hal ini komersialisasi pertanian semakin melembaga di kalangan masyarakat desa. Namun hal ini tidak berarti bahwa dengan demikian petani yang menyikapi pertanian sebagai way of life semuanya menjadi agricultural enterpeneurs yang mengorientasikan usahataninya untuk mengejar keuntungan (profit oriented). Petani yang memiliki lahan luas serta cadangan modal yang kuat dapat mengadopsi modernisasi dan komersialisasi pertanian. Namun petani yang memiliki lahan pertanian sempit atau bahkan tidak memiliki justru mengalami kemerosotan hidup. Sebab, komersialisasi dan modernisasi pertanian menyebabkan retaknya tradisi lama beserta kerukunan-kerukunan yang melekat pada tradisi itu. Akibatnya, komersialisasi dan modernisasi menyebabkan kesenjangan atau polarisasi sosial ekonomi di antara sesama warga petani.

Ditambahkan Raharjo (2004) bahwa untuk masyarakat petani yang telah menggunakan teknologi dan sistem pertanian modern, kerangka wawasan yang lebih tepat adalah perspeksi materialisme. Dalam perspeksi ini, sistem produksi pertanian yang telah kompleks, dengan teknologi modern dan yang orientasinya pada keuntungan, dilihat sebagai dasar yang menentukan bagi corak kehidupan masyarakat petani.

Secara umum, gelombang kekuatan modernisasi seperti komersialisasi, teknologi baru, serta tekanan penduduk merupakan faktor yang sangat berpengaruh terhadap perubahan-perubahan yang terjadi pada masyarakat desa.

Berdasarkan pernyataan di atas memberikan pemahaman bahwa petani di desa memiliki kecenderungan untuk menggunakan teknologi modern sehingga dalam proses berusahatani mengarah pada pola pertanian untuk mencari keuntungan. Hal ini, dapat diartikan bahwa terjadi proses kompleks terhadap kehidupan sehingga petani mengalami dampak dari perubahan-perubahan. Petani berpikir untuk mencari keuntungan sehingga mereka berupaya untuk bertani secara modern. 


\section{METODE PENELITIAN}

Penelitian ini menggunakan pendekatan kualitatif yang merupakan penelusuran data secara kasus dan partisipatorik. Keterlibatan dalam penelitian ini adalah untuk menggali secara mendalam aktivitas petani dan menelusuri aktivitas atau teknik-teknik petani berinovasi dan diversifikasi produksi menjadi kualitas ekspor.

Pembelajaran dan Invensi (Experience)

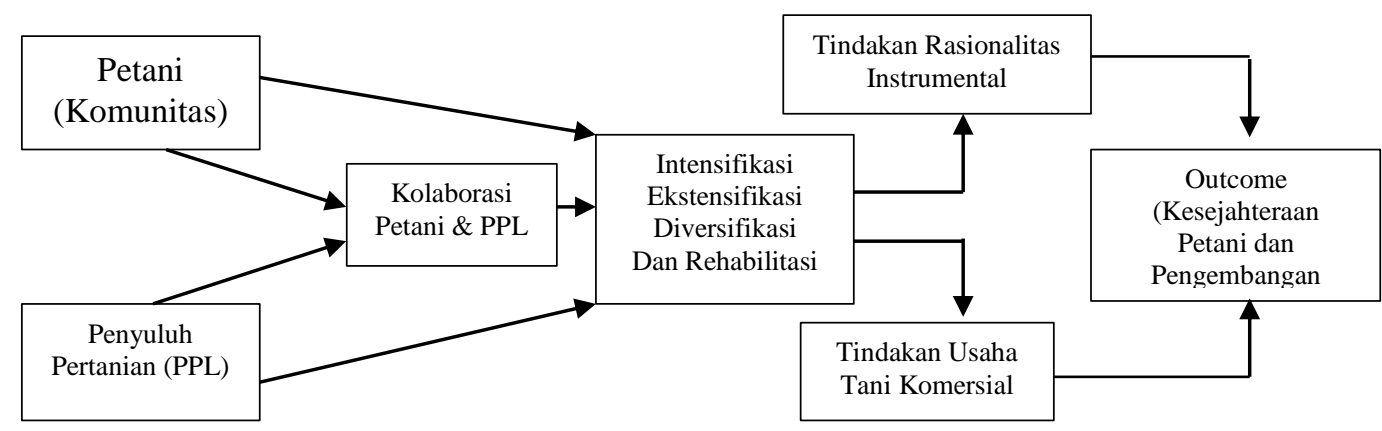

Inovasi (Top Down)

Jenis penelitian ini adalah penelitian kasus petani dan partisipatorik dimana peneliti berada di lokasi untuk memantau dan mengamati secara langsung kegiatan-kegiatan yang dilakukan petani tambak kepiting. Informan penelitian ini adalah petani tambak yang berada di Pallime Kabupaten Bone. Jumlah informan yang akan diteiliti sebanyak 25 informan yang diseleksi secara kategori sebannyak 5 orang tergolong kaya, 15 orang menengah dan 5 miskin. Waktu yang digunakan dalam penelitian adalah 6 bulan secara intensif menelusuri aktivitas petani untuk membuktikan aktivitas yang dilakukan petani. Kegiatan penelitian ini dibantu oleh penyuluh yang informasi tentang teknik intensifikasi dan diversifikasi produk petani. Kemitraan dengan penyuluh yang mendiseminasikan teknik-teknik berusahatani dan berinovasi di bidang pertanian.

Teknik Pengumpulan Data, Data-data yang diperoleh melalui proses wawancara dan juga peneliti terjung langsung di lapangan serta mengamati secara cermat kegiatan petani. Datadata dapat dianalisis dan menemukan inovasi yang dikembangkan oleh petani yang berdasarkan dari pembelajaran sosial dan inovasi-inovasi yang dikemangkan oleh petani. Teknik Analisis Data, Dianalisis data melalui proses wawancara, partisifatorik (FGD focus group discussion) dan verifikasi data untuk pengambilan kesimpulan penelitian serta dianalisis proses pengembangan serta temuan- temuan pengembangan IPTEK di bidang pertanian.

\section{HASIL DAN PEMBAHASAN}

\subsection{Deskripsi Hasil Penelitian}

Berdasarkan temuan di lokasi penelitian maka perlu dipaparkan temuan-temuan dari beberapa informan penelitian ini, namun tidak diuraiakan secara menyeluruh akan tetapi sebagian informan saja sebagai berikut: Informan 1

Seorang penyuluh pertanian yang bernama Alam Syahruddin telah berusaha secara optimal memperkenalkan program intensifikasi, ekstensifikasi, diversifikasi dan rehabilitasi pertanian. Kegiatan tersebut dilaksanakan melalui beberapa kelompok tani untuk dibinanya. Dia membentuk kelompok tani sesuai wilayah yang telah ditetapkan dinas pertanian khususnya di bidang perikanan. Kegiatan tersebut dijalani kurang lebih 10 tahun. Dia membimbing petani untuk mengembangkan kepiting, udang, dan rumput laut. Penyuluh menyampaikan bahwa petani memiliki lahan secara rata 3 hektar lahan dari kelompok tani. Namun ada juga petani hanya mengontrak lahan. Menurut penyuluh menyebutkan bahwa dalam 1 hektar lahan dikontrak dengan senilai 8 juta pertiga tahun. Petani tambak dapat mengontrak lahan dengan memperhitungkan nilai keuntungan, misalkan dalam 1 hektar lahan dapat di panen rumput laut sekitar empat kali dalam setahun dengan 
produksi 2 ton rumput laut sekali panen. Hal ini dapat diperhitungkan bahwa $4 \times 2$ ton $=8$ ton $\mathrm{x}$ $\mathrm{Rp}$ 2.000.000.000. maka dapat diperoleh 16 juta rupiah pertahun.

Menurut petani tambak lebih menyenangi untuk memelihara rumput laut. Sedangkan kepiting, udang, dan ikan bandeng hanya ditebar untuk membantu petani dalam proses penyebarang bibit rumput laut agar merata dalam lahan. Tetapi mereka dapat juga memperoleh nilai tambah bahwa kepiting, udang kaddoro atau udang kecil berwarna putih berkembang secara alami dalam tambak sehingga petani dapat memperoleh tambahan produksi untuk konsumsi dan dapat dijual sebagai penambah pendapatan petani tambak.

Ditambahkan Alam Syahruddin bahwa di Kecamatan Cenrana sudah terdapat pabrik untuk persiapan packing produksi untuk pengelohan rumput laut lebih lanjut. Oleh karena itu petani tambak termotivasi untuk memproduksi rumput laut karena nilai jual selalu tinggi, di samping itu pengusaha sudah siap menerima produksi dari petani.

Informan 2

H. Mahmud berumur 39 tahun mempunyai 7 orang anak. Dia dapat menyekolahkan anakanaknya dari hasil usahataninya. Dia berusahatani sekitar 10 tahun secara mandiri, dia memiliki lahan tambak seluas 8 hektar. Pada awalnya, dia berusahatani ikan, kepiting. Setelah dia melihat perkembangan rumput laut yang dapat berproduksi lebih banyak dan nilai jual yang tinggi, maka dia menfokuskan perhatiannya untuk mengolah lahan tambak dan menebarkan bibit rumput laut. H. Mahmud memperoleh pengetahuan berusahatani dari masyarakat dan menerima informasi yang baik dari penyuluh tentang tata cara pengembangan rumput laut.

H. Mahmud sangat memperhatikan usahataninya dengan menfokuskan pada rumput laut. Dia memperhatikan tata cara pemberian pupuk dan juga dipelajari dengan baik mengenai keadaan air laut di saat air pasang. H. Mahmud memasukkan bibit ikan untuk membantu penyebaran bibit rumput laut. Di samping itu, dia mempelajari tata cara pemupukan rumput laut agar rumput laut dapat menghasilkan produksi kualitas tinggi dan timbangan yang berat. Berdasarkan pengalaman $\mathrm{H}$. Mahmud tentang kepiting agar dapat bertelur maka dia memilih kepiting dan disimpan dalam keramba atau kolam khusus yang sudah dipersiapkan bambu yang telah dibelah-belah dan diberikan makanan khusus seperti pemberian makanan tambahan.
Kepiting yang ditempatkan secara khusus akan bertambah telurnya (kepiting Maddama) memiliki nilai jual yang tinggi disesuaikan dengan bobot berat kepiting. Hal ini dapat menambah pendapatan tetapi membutuhkan pemeliharaan yang serius.

H. Mahmud menjelaskan bahwa pada umumnya petani tambak yang ada di Pallime memfokuskan pemeliharaan rumput laut, karena rumput laut dapat memproduksi lebih banyak dan berkali-kali dipanen dalam setahun. Sedangkan untuk penebaran bibit rumput laut hanya sekali dalam setahun. Petani di Pallime telah memiliki pengalaman yang baik tentang rumput laut. Namun petani terkadang mengalami kendala dalam hal pemeliharaan produksi. Karena produksi rumput laut itu dikeringkan secara alami. Petani mengharapkan bahwa pengolahan produksi berupa pengeringan itu diperlukan teknologi canggih.

Informan 3

H. Wasir seorang petani tambak yang memiliki pengalaman berusahatani selama 20 tahun. Dia menginformasikan bahwa rumput laut kadang tidak berhasil disebabkan karena terlalu banyak bibit dan perlu ada ikan di dalam tambak. Ikan dapat berfungsi untuk memakan lumut. Kalau lumut terlalu banyak dalam tambak akan mempengaruhi proses pertumbuhan rumput laut terhambat dan kualitas rumput laut yang rendah. H. Wasir menjelaskan bahwa rumput laut dikenal sekitar 10 tahun yang lalu. Dia melihat ada orang baru masuk di Pallime yang memperistrikan penduduk asli di Pallime yang menjadi agen pembaharu rumput laut. Ternyata mereka berhasil mengolah rumput laut sehingga masyarakat petani di Pallime mencontohnya dan termotivasi untuk berusahatani.

H. Wasir menjelaskan tentang tata cara pembagian hasil rumput laut bagi pekerja harian adalah Pengambilan panen di tambak dikelola oleh pekerja harian. Jika mereka memanen sekitar 400 kilogram maka pekerja memperoleh 100 kilogram. Mereka bekerja sampai panen itu dapat dijual atau buruh tani mengeringkan panen rumput laut.

Informan 4

H. Rahman berusia 30 tahun. Dia memiliki 6 hektar tambak yang dikelolanya. Dia pernah mengontrak lahan Rp. 7.500 .0000 perhektarnya. Dia sangat menekuni usahataninya untuk memenuhi kebutuhan hidupnya. Dia menjelaskan bahwa permasalahan bagi petani tambak adalah lahan-lahan yang ada di desa Pallime kebanyakan dimiliki oleh orang luar desa 
atau dari kota Kabupaten. Namun petani tambak banyak yang mengontrak lahan saja.

H. Rahman menyampaikan bahwa biaya yang diperlukan dalam satu ton produksi rumput laut sekitar Rp. 1.500.000, sedangkan keuntungan yang diperoleh sebesar Rp. 5.000.000. Jika dalam 1 hektar lahan dapat memproduksi 2 ton rumput laut maka berarti petani memperoleh keuntungan Rp. 10.000.000. Mencermati dari hasil panen yang diperoleh dari 6 hektar maka bapak H. Rahman dapat memperoleh keuntungan sekitar Rp.50.000.000 Rp. 60.000.000 setiap dia panen rumput laut.

H. Rahman memilih untuk pemeliharaan rumput laut dibandingkan hanya mengisi tambaknya hanya ikan bandeng saja. Dia tidak mementingkan untuk ikan bandeng, namun dia mengisi tambaknya yang difungsikan untuk penyebarang bibit rumput laut dalam tambaknya. Dia memperoleh keuntungan tambahan saja tentang ikan bandeng, lagi pula kepiting tidak dipelihara tetapi kepiting memasuki lahannya dan diperoleh hasil tambahan.

\subsection{Pembahasan}

Berdasarkan dari kajian hasil penelitian ini maka dibutuhkan analisis interpretatif dari skorpus data informan-informan dalam penelitian ini. Penelitian ini mengkaji pola rasional instrumental petani tambak secara teliti dipahami kemampuan petani tambak untuk memilih secara rasional tentang komersialisasi. Dari empat piilihan yang ada mengenai udang, kepiting, ikan, dan rumput laut. Maka ditemukan bahwa petani memiliki pilihan yang komersial yaitu teknik pengolahan rumput laut karena rumput laut dapat ditingkatkan produksinya dan nilai jual yang tinggi dan lagi pula rumput laut memudahkan petani dalam proses pemeliharaan, pengembangan bibit dan pengolahan produksi.

Informan dalam penelitian menekankan pentingnya suatu pilihan rasional instrumental dan komersial. Mereka menemukan suatu pilihan komersial pada suatu usahatani yang ditekuninya untuk meningkatkan produksi yang berkualitas agar dapat disesuaikan dengan kualitas harga yang baik pula. Mereka melaksanakan usahatani disesuaikan dengan kemampuannya berinovasi pertanian yang baik. Kemampuan berinovasi di bidang tambak merupakan suatu kemampuan yang telah diperoleh melalui suatu proses perkembangan ilmu pengetahuan dan teknologi yang dihadapi oleh petani tambak.
Informan penelitian ini menjelaskan bahwa mereka dapat mendesiminasikan temuantemuan dalam proses pengelolaan tambak. Mereka mempelajari lingkungannya terutama keadaan cuaca/iklim di pallime. Mereka memahami keadaan bulan yang paling tepat untuk menebar bibit. Selanjutnya informan penelitian ini memiliki skill dalam pengaturan jadwal tabor bibit dan jadwal panen rumput laut. Mereka memperlajari cuaca untuk pengaturan produksi untuk pengeringan produksi.

Informan penelitian ini memilih rasional instrumental dan komersial terhadap salah satu produksi tambak khususnya adalah rumput laut yang dipahami dapat memberikan keuntungan yang tertinggi dibandingkan produksi kepiting, ikan bandeng, kepiting.

\section{KESIMPULAN}

Berdasarkan dari kajian teori, hasil penelitian dan pembahasan maka dapat disimpulkan bahwa rasional instrumental dan komersial petani tambak di Pallime Kabupaten Bone. Petani tambak memilih suatu usahatani yang memiliki nilai keuntungan yang tinggi untuk memenuhi kebutuhan pokok dan kebutuhan peningkatan kesejahteraan petani tambak. Komunitas Petani tambak di Pallime Kabupaten Bone berusahatani secara rasional instrumental dan komersial.

\section{DAFTAR PUSTAKA}

Narwoko, J.Dwi. (2006). Sosiologi, Teks Pengantar dan Terapan. Jakarta: Kencana Prenada Media Grup.

Raharjo. (2004). Pengantar Sosiologi Pedesaan dan Pertanian. Yokyakarta: Gadjah Mada University Press.

Salman. Darmawan. (2006). Jagad Maritin.Makassar: Ininninawa.

Sanderson K. Stephen. (1995). Sosiologi Makro, Sebuah Pendekatan terhadap Realitas Sosial. Jakarta: Raja Grapindo Persada.

Wolf, R. Eric. (1983). Petani suatu Tinjauan Antropologi. Jakarta: Rajawali. Yulianto. Yayuk. 2003. Sosiologi Pedesaan. Yokyakarta: Lappere Pustaka Utama. 